\title{
THE PERFORMANCE OF THE SMES IN POLAND DURING AND AFTER FINANCIAL CRISIS AND ECONOMIC DOWNTURN - ON THE EU-28 BACKGROUND
}

\section{DOMINIKA KORDELA}

University of Szczecin, POLAND

e-mail: dominika.kordela@wzieu.pl

\section{RECEIVED \\ ACCEPTED \\ JEL \\ CLASSIFICATION \\ KEYWORDS}

ABSTRACT

\author{
1 May 2018 \\ 1 September 2018 \\ L25, G30, G39
}

SMEs performance, SME finance, SME development, financial crisis

The aim of the paper is to assess the financial condition of micro, small and medium-sized enterprises in Poland during and after financial crisis 2008-2010 and the economic downturn.

In this paper a thesis was advanced that the consequences of the downturn were felt by the entire sector, but each group of the companies was affected to a different degree.

The companies in the sector of SME were assessed based on selected financial data. Moreover, the article includes assessment of the sector's importance for the polish economy. The analysis is based on data from secondary sources published by Central Statistical Office, Eurostat and Polish Agency for Enterprise Development. The temporal scope of the study encompasses the years 2007-2016.

The analysis of selected financial data is enough to state that although the economic downturn led to a temporary fall in the revenue level, financial result or profitability, the economic standing of the sector generally improved throughout the period analysed (2007-2016).

\section{Introduction}

Micro, small and medium-sized enterprises constitute $99.8 \%$ of all economic entities in Poland. The significance of this group of entities for the economic growth and employment is unquestionable, which is proved by scientific research and numerous reports. Qimiao Fan indicates that SME's are not only an engine for the growth but also essential for competitive and efficient market as well as critical for the poverty reduction (Fan, 2003). 
The importance of SME's for economic growth, as well as creating the competitive private sector has been proven in many studies (e.g. Ayyagari, Beck, Demirguc-Kunt, 2003; Beck, Demirguc-Kunt, Levine, 2003; Rahman, 2010).

The economic crisis (2008-2010) resulted not only in bearish sentiments on stock exchanges, problems of financial institutions and sovereign debt crisis of some of the European countries, but in economic problems across Europe as well, manifesting themselves in the downturn, or even recession.

Against the background of Europe, Poland turned out to be relatively resistant to the transmission of turbulences on the financial market to the real economy. Nevertheless, the economic downturn did affect Poland, which was why studies on the condition of the sector were commenced. Nevertheless the financial crisis also has its beneficiaries, it teaches humility and modesty, it gives new impulses (Sadowska, 2010). It is possible that the beneficiaries might be SMEs.

The aim of the present paper is to assess the condition of the sector of micro, small and medium-sized enterprises in Poland in the times of the economic downturn following the financial crisis till 2016. A thesis was advanced that the consequences of the downturn were felt by the entire sector, but each group of the companies was affected to a different degree. The companies in the sector of small and medium-sized enterprises were assessed based on selected financial data (revenues, financial result, profitability, investment). Moreover, the article includes assessment of the sector's importance for the economy, performed through the determination of their participation in the added value or employment. The analysis is based on data from secondary sources published by the Ministry of Economy, Central Statistical Office, Eurostat and Polish Agency for Enterprise Development. The dynamics of the basic financial data and digits typical of the sector of micro, small and medium-sized enterprises were analysed.

The paper is organized as follows: the second chapter presents a brief view on the economic situation in Poland in 2008-2016. The third chapter describes the economic significance of micro, small and medium-sized enterprises in Poland comparing with EU-28 and then the fourth discusses the development and financial standing of micro, small and medium-sized companies in 2007-2016. The final part contains conclusion.

\section{The view on the economic situation in Poland in 2007-2016}

The real economy in Poland started to feel the consequences of the financial crisis later than the countries of the European Union or the USA, namely, in 2009. Between 2006 and 2007, the GDP pace exceeded 6\% per annum and was twice as high as in the EU Member States. In the years 2007-2012, despite drops on the stock exchange and a significant downslope of the GDP growth rate in the EU, in Poland, the GDP was still positive. In next years between 2013-2016 the growth of GDP both in Poland and EU-28 showed the similar tendency and was in both cases positive (Figure 1).

Next to the drop in the GDP dynamics, there were other signals of the economic downturn in Poland, like decided drop in investment dynamics or rise in unemployment. Dynamic of the investment was positive in 20072008, then there was decrease in 2009 and very low growth in 2010. In the exception year 2011 the growth was recorded, but as it is visible on Figure 2 there was no clear positive tendency in this area. The polish entitles were careful in deciding on investments. 


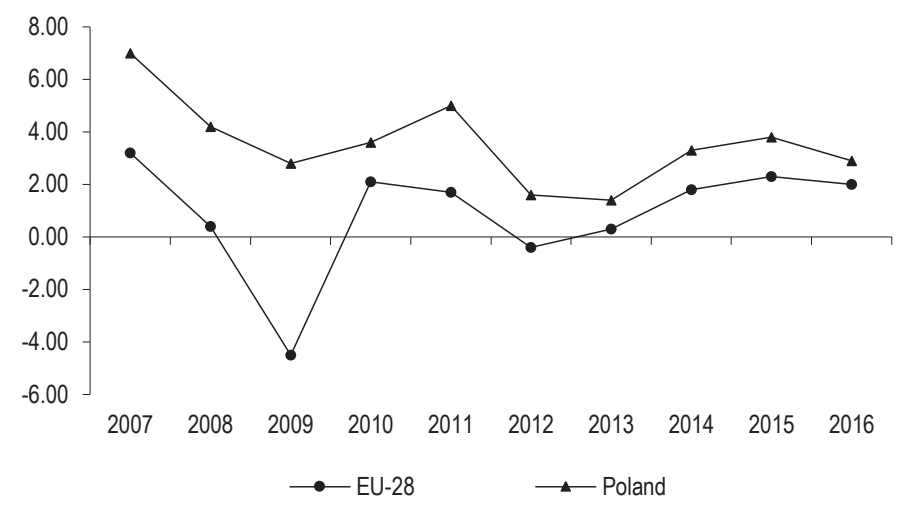

Figure 1. Real GDP growth rate in EU-28 and Poland in 2007-2016

Source: Eurostat.

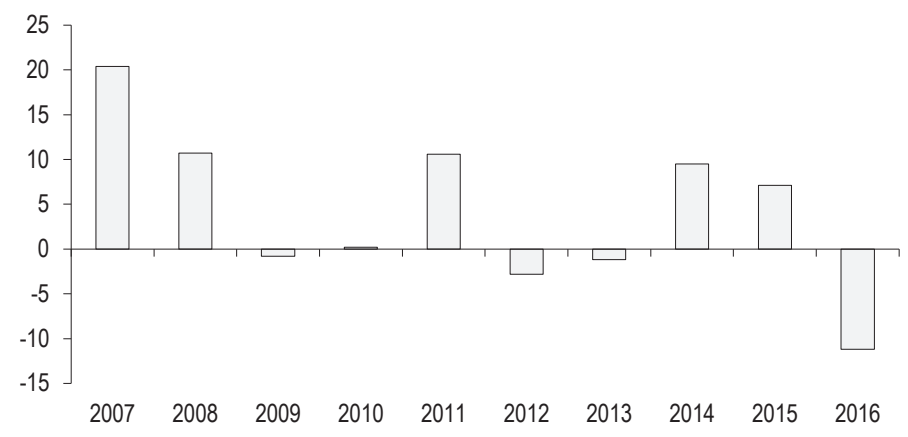

Figure 2. Investment Dynamics in Poland 2007-2016

Source: Central Statistical Office.

\section{Economic significance of micro, small and medium-sized entepprises in Poland in 2008-2016 - main issues}

The Polish Act on Freedom of Economic Activity stipulates the same criteria for distinguishing company categories, divided by size, as are in place in the European Union. ${ }^{1}$ Similarly to the European Union, the dominant type of companies in Poland are micro companies, which constitute $96 \%$ of the total number of enterprises (Działalność przedsiębiorstw..., 2016). Their participation in the overall number of all companies is higher than the average in the EU, which might be caused by the high self-employment rate in Poland. On the other hand, the number of small companies is lower when compared to the average of all EU countries. This, in turn, might suggest potential problems with the development of the activity from the micro to the small scale.

\footnotetext{
${ }^{1}$ There are: the number of employees, the value of turnover and the value of balance sheet total.
} 
Participation in added value and participation in creation the workplaces are commonly used criteria for assessing the importance of the sector of micro, small and medium for the economy of the particular country. The table below presents the comparison of the strength of SME's in European Union and Poland, the presented indicators are used by European Union's institutions for assessment of the importance of the sector for the economy.

Table 1. The percentage of companies, percentage of the employed and participation in added value - micro, small and medium-sized companies in Poland and in the European Union in $2016^{2}$

\begin{tabular}{lcccc}
\hline & Micro & Small & Medium-sized & Total \\
\hline EU-27 & Participation of individual size groups in the overall & number of enterprises & \\
Poland & 93.0 & 5.8 & 0.9 & 99.8 \\
\hline \multicolumn{5}{c}{} \\
\hline EU-27 & 36.0 & Employment & 0.8 & 99.8 \\
\hline Poland & 29.8 & 20.0 & 16.7 & 66.5 \\
\hline EU-27 & 36.8 & 13.9 & 17.8 & 68.5 \\
Poland & 20.9 & Added value & 56.8 \\
\hline
\end{tabular}

Source: Muller et al. (2017).

According to Annual Report on European SME's prepared by European Commission micro, small and mediumsized companies in Poland create $68.5 \%$ of workplaces. The great significance on employment have especially micro companies that engage more that $36 \%$ of the workforce in Poland. As previously mentioned the higher rate than EU-average (29.8\%) is caused by high level of self-employment which actually is type of micro-enterprise.

In accordance with the data by Eurostat the sector generate in Poland added value at the level of $52.6 \%$. As indicated by the Eurostat data, the participation of the sector of micro, small and medium-sized companies in Poland in gross added value is lower than the EU average. Data in the table 1 point to the significantly smaller participation of the micro and small companies in added value and bigger than in the EU added value generated by medium-sized enterprises.

The data mentioned above indicates that micro, small and medium entitles play a very important role in a national economy of Poland similarly like it is in other EU-member states. Although the significance and the strength of both the entire sector and the each group of companies differs from EU average.

\section{Development and financial standing of micro, small and medium-sized companies in 2008-2016}

Although, in principle, in the period subject to the study (when we compare 2016 to 2007), the number of companies in all groups of the sector grew (Table 2), the data point to significant growth in the number of enterprises liquidated in 2008 (small and medium-sized ones), in 2009 (micro) and in 2011 - back then. The number of liquidated entitles grew (especially in 2008 and 2011), however the number of active in 2008 and 2011 was higher than in the previous year. Which actually may suggest that in this period there was a growth of the new registered companies

2 In accordance with the methodology of Eurostat, the number of companies does not include the economic entities which run business activity in the following sectors: agriculture, forestry, fishing industry, educational services, health protection sector. 
but actually the issue is more complicated. The data of Polish Agency for Enterprise Development consists the information about: total number of registered enterprises, the number of active enterprises, the number of new registered enterprises and the number of enterprises liquidated. Analysis of these data indicates that in 2008 there was an increase in the number of new registered companies in each group of the sector (comparing to 2007) but in 2011 the increase was noticed only in the group of small and medium companies.

Table 2. Number of active enterprises in sector SME in years 2008-2016 in thousands

\begin{tabular}{lrrrrrrrrr} 
& 2008 & 2009 & 2010 & 2011 & 2012 & 2013 & 2014 & 2015 & 2016 \\
\hline Micro & $1,714.8$ & $1,604.4$ & $1,655.1$ & $1,710.6$ & $1,719.2$ & $1,693.8$ & $1,764.6$ & $1,838.4$ & $1,937.2$ \\
Small & 54.3 & 50.2 & 52.6 & 55.0 & 57.1 & 59.1 & 59.2 & 56.7 & 57.2 \\
Medium & 16.1 & 15.8 & 15.8 & 15.8 & 15.5 & 15.3 & 15.5 & 15.6 & 15.4 \\
\hline
\end{tabular}

Source: own study based on data of the Raport o stanie sektora... (2017) and Reports: Działalność przedsiębiorstw...

The research published in Report on the condition of the sector of small and medium-sized companies in Poland indicates that over the years 2008-2016 the number of newly created enterprises was higher than the number of liquidated enterprises (with exception in 2009 and 2011). This situation could be generally assessed positively, however the number of de-registered enterprises grew slightly faster compared to the number of newly created companies.

The diagnosis of the financial situation of the SMEs sector in Poland has been based on following elements: revenues from total activity, gross financial result, profitability rate of gross turnover.

The Figure 3 presents the revenues in SME's - it is visible that the toughest year was 2009. In 2007-2016, the enterprises reported growth in revenue (assuming that 2007 was the base year). In micro firms revenues grew by $29 \%$, the highest grow amounted $33 \%$ in small companies, and the revenues of medium entitles increased by $20 \%$. The dynamic in 2012 and 2013 was very low (except small companies), in following years the strongest growth reported micro firms. The micro and the medium companies had higher revenues but on the other hand the small companies had the greatest dynamic of the growth in revenues in 2008, 2010, 2011.

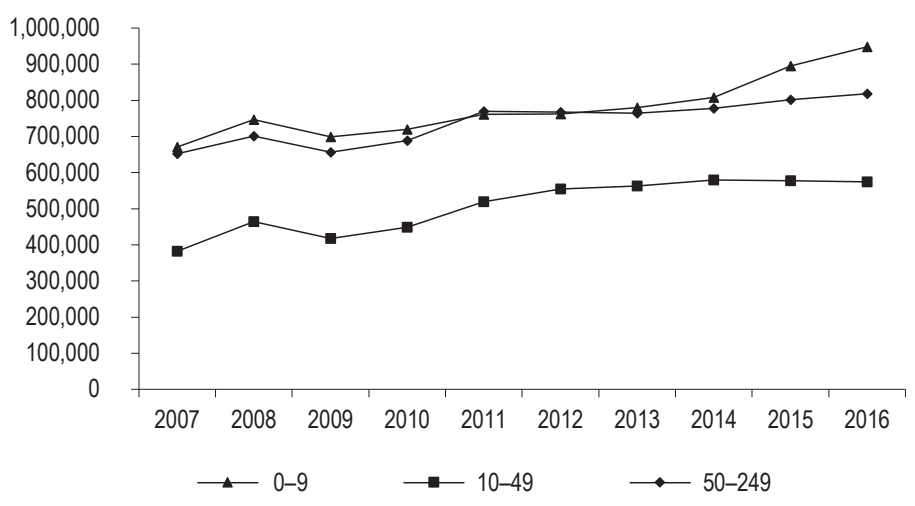

Figure 3. Revenues from total activity in mIn PLN

Source: own study based on data of the Raport o stanie sektora... (2013) and Reports: Działalność przedsiębiorstw... 
It can be said that the financial crisis and economic downturn did not significantly affect the sector of small and medium-sized companies in terms of revenue. The dynamics of the growth in the revenue (YoY) in all groups was negative only in 2009. It afflicted small enterprises the most (-10\%), while micro and medium-sized companies reported a drop by $6 \%$. In medium-sized companies the dynamics of revenues was as well negative in 2012 and 2013 , in the group of small-sized companies was negative in 2015 and 2016. Actually the best conditions - in terms of the dynamics in the revenues - during hole period were among micro and small companies. Namely comparing 2016 and 2007 it was increase of respectively 41 and $50 \%$.

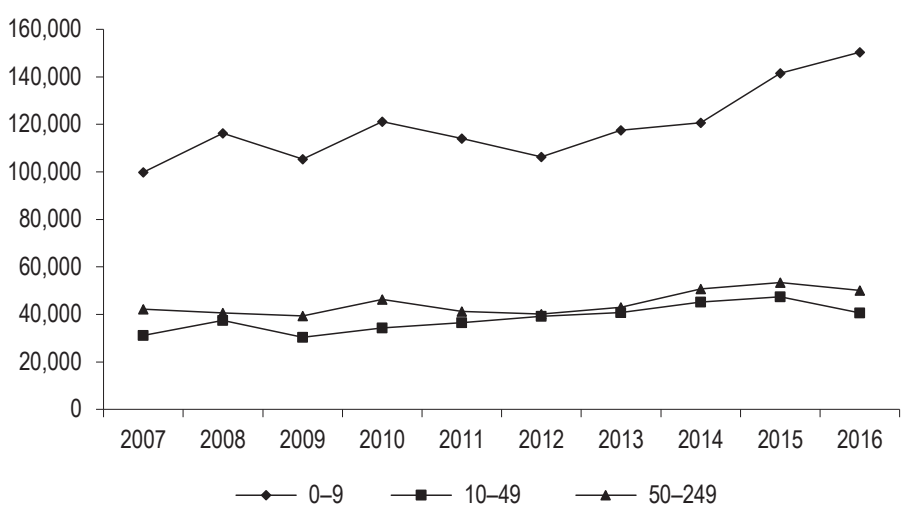

Figure 4. Gross Financial Result

Source: own study based on data of the Raport o stanie sektora... (2013) and Reports: Działalność przedsiębiorstw...

Analysis of the gross financial result points to the heterogeneity of the sector of micro, small and mediumsized companies in this scope. Micro-companies reported negative financial result dynamics in 2009, 2011 and 2012, while in small companies, the pace of the growth was negative in 2009 (amounted to -19\%) and in 2014 - as well quite deep drop by more than $14 \%$. Medium-sized companies coped with downturn in the financial result the worst (the negative growth pace was reported in 2008, 2009, 2011, 2012 and 2016). The recovery of medium-sized companies was the weakest among SMEs - the growth of revenues comparing 2016 and 2007 amounted 19\%, and was lower than in micro and small onces.

Assessment of the level of profitability of gross turnover is indicative of its relative stability in the period analysed (differences from 1 to $3 \%$ in each group). The highest rate in the sector of micro, small and medium-sized companies belongs to micro-companies and in the period in question fluctuated between 11.40 (the lowest in 2012) and $17.57 \%$. The profitability of small companies was the poorest in 2011 and in 2016 (respectively 6.58 and 5.5\%). Medium-sized companies are characterized by the lowest profitability in the entire sector (between $4.0 \%$ in 2012 and $6.73 \%$ in 2010 ).

The downturn in the economy causes the restricted expenses' decision in companies. Analysis of the expenditures on investments indicates that micro-companies increased them successively throughout the period analysed, while small and medium-sized companies reduced their expenses in 2009-2010. But actually differences in each group during hole analysed period (2007-2016) were not very high. 


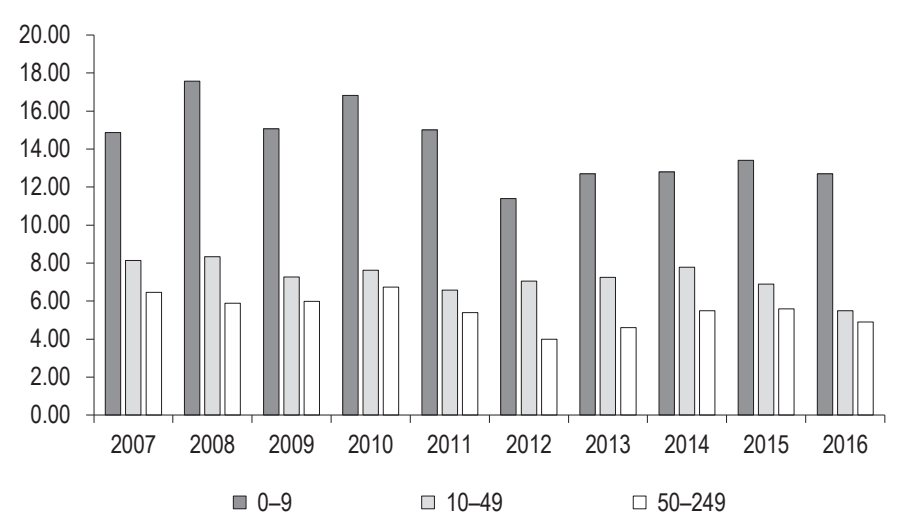

Figure 5. Gross turnover profitability rate in percentage

Source: own study based on data of the Raport o stanie sektora... (2013) and Reports: Działalność przedsiębiorstw...

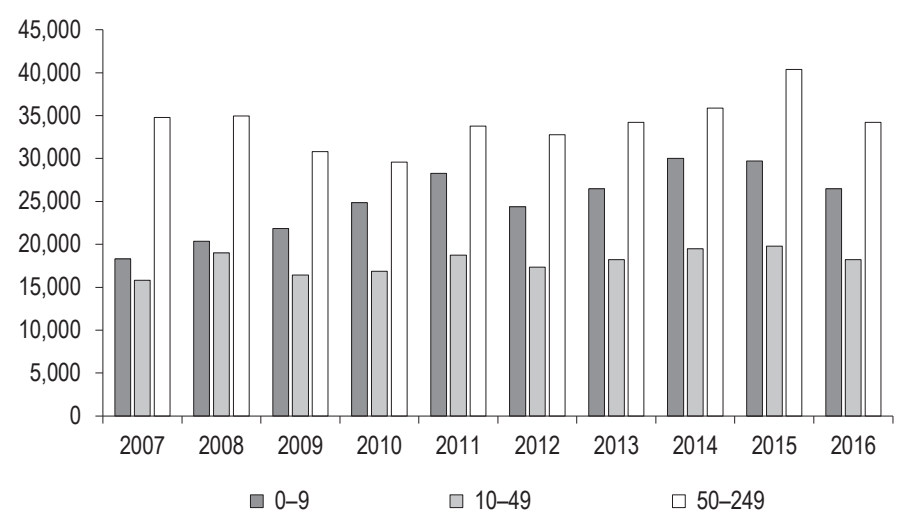

Figure 6. Total investment outlays in PLN millions

Source: Source: own study based on data of the Raport o stanie sektora... (2013) and Reports: Działalność przedsiębiorstw...

The data presented above indicate that polish SMEs have already recover from the consequences of the financial crises and the economic downturn. Moreover performance figures presented in the Annual Report on European SMEs (pp. 27-28) at EU-28 level show very positive developments of this group of entitles in Poland and proof a strong recovery from the last financial crisis and economic downturn. It is worth to add that Poland is among nine $^{3} \mathrm{EU}$ countries that show complete recovery in terms of number of SMEs, employment in this sector and added value created in this group of entitles.

${ }^{3}$ The other eight member states are: Austria, Belgium, Finland, Germany, Luxemburg, Malta, Sweden and the United Kingdom. 


\section{Conclusions}

The analysis of selected financial data is enough to state that although the economic downturn led to a temporary fall in the revenue level, financial result or profitability, the economic standing of the sector generally improved throughout the period analysed (2007-2016). 2009 was definitely the most difficult year. An improvement in the condition of enterprises in 2010 allowed for an increase in all important financial indicators.

We can hazard a guess that it was the micro-companies that handled the downturn best. Apart from 2009, they reported growths in revenue - the pace of their growth was only negative in 2009 and their investments as well grew (except 2012 and 2016), so they boasted the highest gross turnover profitability ratio when compared to the rest of the sector.

Against the background of the sector, it was the medium-sized companies that handled the economic downturn the worst. In 2008, 2009, 2011 and 2012 the dynamics of their financial result were negative and their expenditures on investment in 2009, 2010 and 2012 dropped as well. Moreover, this group of companies is characterised by the lowest level of gross revenue profitability in the whole sector.

The studies and analyses confirm the thesis that the economic downturn affected each of the size groups of the sector of small and medium-sized companies to a different degree and had different impacts on the indicators of the assessment of their condition.

\section{References}

Ayyagari, M., Beck, T., Demirguc-Kunt, A. (2003). Small and Medium Enterprises across the Globe: A New Database. World Bank Policy Research Working Paper 3127, August.

Beck, T., Demirguc-Kunt, A., Levine, R. (2003). Small and Medium Enterprises, Growth, and Poverty: Cross-Country Evidence. World Bank Policy Research Working Paper 3178, December.

Fan, Q. (2003). Importance of SMEs and the Role of Public Support in Promoting SME Development. Presentation from World Bank Workshop, St. Petersburg, Russia September 1-16.

Muller, P., Julius, L., Herr, D., Koch, L., Peycheva, V., McKiernan, S. (2017). Annual Report on European SMEs 2016/17. Focus on self-employment. European Commission. Retrieved from: https:/lec.europa.eu/growth/smes/business-friendly-environment/ performance-review_pl (20.03.2018).

Rahman, K.A. (2010). Development of Small and Medium Scale Enterprise in Bangladesh: Prospects and Constraints. Bangladesh Institute of Bank Management.

Raport o stanie sektora małych i średnich przedsiębiorstw w Polsce w latach 2011-2012 (2013). Wraszawa: Polish Agency for Enterprise Development.

Raport o stanie sektora małych i średnich przedsiębiorstw w Polsce (2017). Warsaw: Polish Agency for Enterprise Development. Retrieved from: www.parp.gov.pl.

Reports: Działalność przedsiębiorstw niefinansownych in 2012, 2013, 2014, 2015, 2016. Retrieved from: www.stat.gov.pl.

Sadowska, B. (2010). Kryzys finansowy głównym problemem ekonomicznym. Zeszyty Naukowe Uniwersytetu Szczecińskiego. Współczesne Problemy Ekonomiczne. Globalizacja. Liberalizacja. Etyka, 2, 75-81.

Cite this article aS: Kordela, D. (2018). The performance of the SMEs in Poland during and after financial crisis and economic downturn - on the EU-28 background. European Journal of Service Management, 3 (27/1), 119-126. DOI: 10.18276/ejsm.2018.27/1-14. 